\title{
Prototipe Sistem Reservasi Daring Dokter Gigi di RSGM Berbasis User Centered Design
}

\author{
Mira Suryani ${ }^{1}$, Arinda Fathya ${ }^{2}$, Dani Rizali Firman ${ }^{2}$, dan Iwa Rahmat Sunaryo ${ }^{2}$ \\ ${ }^{1}$ Departemen Ilmu Komputer, Universitas Padjadjaran, Jatinangor, Sumedang, Indonesia \\ ${ }^{2}$ Departmen Kedokteran Gigi, Universitas Padjadjaran, Jatinangor, Sumedang, Indonesia \\ \{mira.suryani, dani.firman, iwa.sunaryo\}@unpad.ac.id, arinda.fathya@gmail.com
}

\begin{abstract}
Abstrak: Kemudahan reservasi di fasilitas pelayanan kesehatan dapat berpengaruh terhadap tingkat kepuasan pasien. Sejalan dengan perkembangan teknnologi, saat ini masyarakat sudah sangat terbiasa menggunakan smartphone untuk berbagai aktivitas termasuk mengakses layana kesehatan. Berdasarkan situasi tersebut, dalam rangka upaya peningkatan kepuasan pasien di RSGM Universitas Padjadjaran, maka terdapat peluang untuk mengembangkan aplikasi reservasi daring. Pengembangan prototipe berbasis user centered design menjaga pengembangan untuk terus sesuai dengan kebutuhan target pengguna RSGM Universitas Padjadjaran. Berdasarkan hasil uji coba, prototipe yang dikembangkan memiliki tingkat usabilitas yang sangat baik terutama untuk aspek efektivitas serta efisiensi, respon waktu, kepuasan dan kemudahan dalam penggunaannya. Secara keseluruhan, prototipe ini memenuhi kualitas baik untuk digunakan dengan nilai rata-rata skala Likert 3,80 untuk tujuh aspek uji usabilitas.
\end{abstract}

Kata Kunci: Integrasi layanan kesehatan; reservasi daring; user centered design; usabilitas

Abstract: $\quad$ The ease of reservation in health care facilities can affect the level of patient satisfaction. In line with technological developments, nowadays people are very accustomed to use smartphones for various activities including accessing health services. In order to increase the level of patient satisfaction in, there is a challenge to develop online reservation application. The development of prototype using user centered design keeps the development in line with the needs of RSGM Universitas Padjadjaran target users. Based on the experiments, the developed prototype has an impressive level of usability, especially for the effective, response time, satisfaction and ease of use aspects. Overall, this prototype meets good quality for use with an average Likert scale about 3.80 for the seven aspects of the usability test.

Keywords: Integration of health services; online reservation; user centered design; usability 


\section{PENDAHULUAN}

Efisien sistem perawatan kesehatan telah menjadi isu yang penting saat ini. Adanya peningkatan pembiayaan kesehatan, kebutuhan perawatan kesehatan serta ekspektasi kualitas pelayanan merupakan dorongan utama pengembangan sistem perawatan kesehatan untuk terus ditingkatkan (Chen et al., 2018). Sistem pelayanan yang efisien sangat dibutuhkan dalam pengelolaan instalasi rawat jalan (Ahmadi-Javid et al., 2017; Marynissen \& Demeulemeester, 2019). Salah satu komponen yang penting dalam sistem pelayanan kesehatan adalah sistem reservasi. Sistem reservasi yang tidak efisien mempengaruhi lamanya waktu menunggu pasien untuk ditangani dokter. Hal tersebut sangat mempengaruhi tingkat kepuasan pasien dan juga kualitas pelayanan instalasi. Ditambah lagi pada saat pandemi covid-19 ini, akses masyarakat ke layanan kesehatan seperti puskesmas dan rumah sakit dibatasi. Namun, kebutuhan akan layanan kesehatan terutama pemerikaan dan tindakan oleh dokter sering kali tidak dapat diabaikan.

Perencanaan sistem reservasi pasien merupakan hal yang cukup menantang, karena adanya ketidakpastian mengenai waktu yang diperlukan untuk perawatan maupun kehadiran pasien. Pasien yang telah mendaftar bisa saja tidak hadir (no shows) yang disebabkan oleh beberapa hal, antara lain adalah adanya biaya tambahan yang tidak ditalangi asuransi, belum tuntasnya persiapan untuk melakukan prosedur yang akan dijalani, adanya masalah transportasi, hingga pasien lupa (Berg et al., 2014; Chen et al., 2018; Song et al., 2019).

Permasalahan sistem reservasi juga dialami oleh RSGM Unpad. Permasalahan utama dalam berobat di RSGM Unpad adalah antrian yang memakan waktu lama dimulai dari proses reservasi hingga konsultasi. Selain itu, semua kegiatan yang bersifat administrasi masih dilakukan secara manual (offline). Hal ini menyebabkan pasien mengeluh untuk melakukan satu janjian saja dapat menunggu 30-60 menit. Oleh karena itu untuk mengurangi waktu menunggu, janji temu dengan metode antrian online sangat dibutuhkan.

Di sisi lain, berdasarkan hasil penelitian Kurtzman et al. (2018), sistem reservasi daring mampu menjadwalkan perawatan pasien tanpa harus mendaftar atau menelpon ke rumah sakit. Sistem ini dapat menghilangkan proses antrian di rumah sakit dan nomor antrian dapat dipantau melalui smartphone atau halaman website (Wang et al., 2018). 
Berdasarkan hal tersebut, penelitian ini menganalisa kebutuhan reservasi daring yang sesuai dengan keinginan pasien dan tetap memenuhi prosedur di RSGM Universitas Padjadjaran. Hasil rancangan kemudian diimplementasikan ke dalam prototipe sistem reservasi daring untuk RSGM Universitas Padjadjaran. Harapannya sistem reservasi daring ini memiliki tingkat kebergunaan yang baik.

\section{TINJAUAN PUSTAKA}

\subsection{Manajemen dan Administrasi Rumah Sakit}

Manajemen merupakan proses pengelolaan sumber daya, meliputi keuangan, manusia, material, dan fasilitas yang termobilisasi secara ideal, efisien, dan efektif untuk mencapai tujuan suatu institusi. Prinsip manajemen melekat pada fungsi manajemen yaitu perencanaan, pengelolaan, kepegawaian, kepemimpinan, dan pengawasan (Siddiqui, 2016). Dalam domain kesehatan, manajemen dibagi ke dalam dua bentuk yaitu tradisional dan industri. Manajemen tradisional didasarkan pada pengalaman, edukasi dan intuisi dengan proyeksi linear. Sedangkan manajemen industri didasarkan pada model sistematis dari sistem real yang bertujuan untuk membangun pilihan manajerial yang adil (Marynissen \& Demeulemeester, 2019).

Dalam pengelolaan rumah sakit, manajemen yang baik erat kaitannya dengan administrasi yang efisien. Administrasi rumah sakit meliputi beberapa aktivitas yang dikategorikan sebagai berikut: persiapan legislasi rumah sakit, pelaksanaan legalisasi rumah sakit, dan aktivitas keseharian rumah sakit yang dikelola oleh staf administrasi pada bagian internal, keuangan hingga servis teknis, termasuk pada aspek reservasi (Siddiqui, 2016).

\subsection{Sistem Reservasi Rumah Sakit}

Sistem reservasi disediakan oleh pengelola rumah sakit untuk meningkatkan efisiensi, produktivitas, dan profit di bidang kesehatan. Salah satu dari kategori sistem reservasi adalah sistem operasional meliputi keputusan jangka pendek menyangkut efisiensi penjadwalan dan pengaturan alur pasien secara individu (Ahmadi-Javid et al., 2017).

Salah satu bentuk sistem reservasi dalam rumah sakit adalah sistem reservasi rawat jalan. Reservasi pada rawat jalan selanjutnya berkaitan dengan mekanisme 
penjadwalan. Dulu penjadwalan dilihat dari urutan kedatangan setiap pasien (offline). Saat ini selain offline, proses reservasi juga dapat dilakukan secara online. Pada reservasi online, pasien akan dijadwalkan berdasarkan permintaan pasien. Seiring meningkatnya kebutuhan akan pelayanan kesehatan, muncul penjadwalan stochastic online yang merupakan perluasan dari penjadwalan online, mempertimbangkan potensi permintaan pasien yang akan muncul dibanding dengan permintaan pasien saat itu (Ahmadi-Javid et al., 2017). Reservasi online mulai digunakan karena kecenderungan meminimalisasi waktu mengantri pasien, meningkatkan kepuasaan pasien dan memudahkan pasien melakukan penjadwalan di mana saja tanpa harus datang ke rumah sakit terlebih dahulu (Zhao et al., 2017).

\subsection{User Centered Design}

User Centered Design (UCD) merupakan pendekatan berorientasi proyek untuk perkembangan sistem yang interaktif didasarkan pada ilmu ergonomik dan kegunaan untuk menemukan kebutuhan pengguna. Terdapat beberapa prinsip dalam UCD yang perlu dipahami untuk menghasilkan desain interaktif. Pertama, proyek yang dikembangkan harus berdasarkan pemahaman eksplisit target pengguna, tugas pengguna dan lingkungannya. Kedua, pengguna diupayakan terlibat di setiap tahapan pengembangan proyek termasuk melakukan penilaian yang berfokus pada pengguna. Ketiga, proses desain bersifat iteratif dengan maksud menyempurnakan spesifikasi desain, meminimalkan resiko tidak tercapainya persyaratan dan harapan pengguna. Keempat, desain yang dikembangkan harus berdasarkan pengalaman pengguna (user experience). Kelima, tim proyek harus mencakup keterampilak dan perspektif multidisiplin dan penting untuk mendalami domain di mana desain diaplikasikan (Chammas et al., 2015).

Pembuatan desain berbasis pengguna bertujuan untuk mendapatkan desain yang ergonomik, memiliki tingkat kebergunaan (usabilitas) yang baik, dan sesuai dengan kebutuhan pengguna. Desain tersebut dapat diperoleh dengan mengimplementasikan tiga fase UCD secara garis besar, yaitu konsep, prototipe (purwarupa) dan evaluasi (Smaradottir \& Fensli, 2016). Setelah fase konsep selesai, dilanjutkan dengan pembuatan desain terdiri atas 3 tahapan yaitu menentukan konteks penggunaan, menentukan spesifikasi pengguna, dan pembuatan solusi yang sesuai kebutuhan 
pengguna. Pada tahapan akhir evaluasi dilakukan berdasarkan target awal yang ditetapkan oleh pengguna (Römer \& Bruder, 2015).

\subsection{Uji Usabilitas}

Menurut Parsazadeh et al. (2018), uji usabilitas merupakan teknik evaluasi yang didasarkan pada persepsi pengguna untuk mengidentifikasi masalah kebergunaan. Upaya meminta pendapat pengguna adalah salah satu metode yang paling umum diadopsi untuk mengevaluasi kebergunaan suatu aplikasi. Pada uji usabilitas terdapat enam aspek yang menjadi poin penilaian yaitu: efektivitas dan efisiensi, tingkat kepuasan, respon waktu, kemudahan untuk dipelajari, kemudahan untuk diingat, penanganan error, dan beban kognitif.

\section{METODE PENELITIAN}

\subsection{Tahapan Penelitian}

Gambar 1. Proses User Centered Design berdasarkan ISO 9241-210:2010(E)(Saito \& Ogawa, 1994)

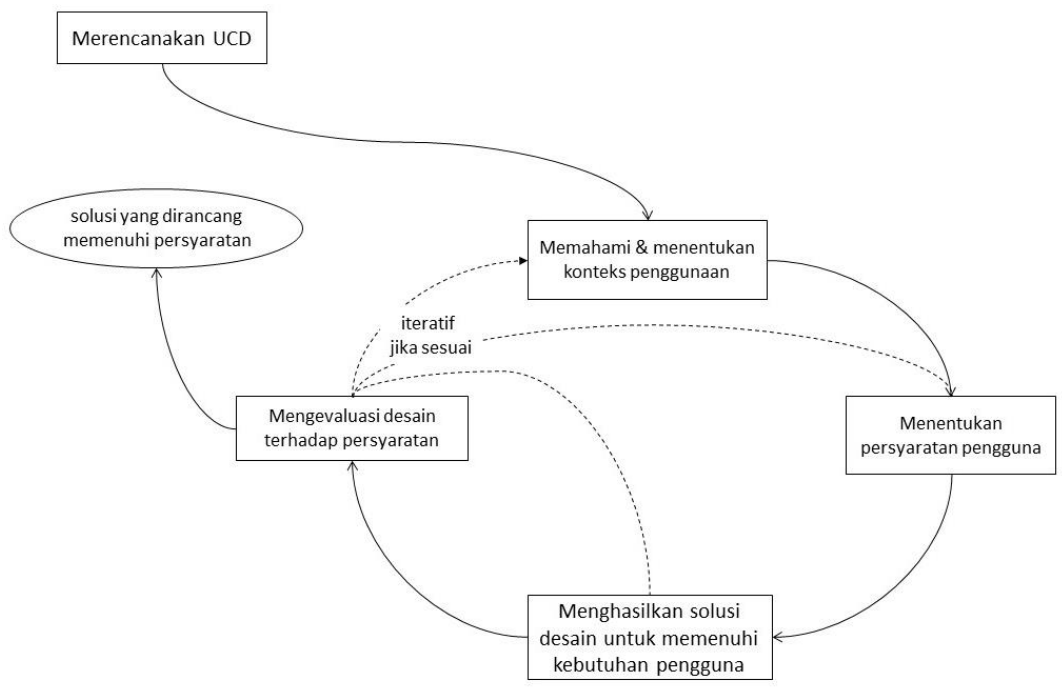

Tahapan penelitian yang dilakukan menggunakan proses UCD seperti pada Gambar 1. Kegiatan memahami dan menentukan konteks pengguna dilakukan dengan mengidentifikasi proses reservasi secara offline di RSGM Unpad. Kegiatan menentukan persyaratan pengguna dilakukan dengan menganalisis data rekam medik untuk menentukan target persona (end user) dari prototipe dan melakukan wawancara individu untuk memahami kebutuhan prototipe reservasi rawat jalan di RSGM. Konteks penggunaan dan target persona dianalisa kemudian dirancang solusi desainnya dan 
dievaluasi. Proses evaluasi dilakukan pada setiap tahapan UCD, namun evaluasi yang disoroti mendalam dalam penelitian ini adalah pada evaluasi akhir satu iterasi dengan menggunakan tes usabilitas.

\subsection{Populasi dan Sampel Penelitian}

Populasi penelitian adalah administrasi RSGM dan pasien yang datang ke RSGM Unpad, Sekeloa, Kota Bandung, Jawa Barat dalam kurun waktu tertentu. Pemilihan pasien sebagai sampel menggunakan teknik clustering, dengan cara pengambilan data rekam medik. Penentuan sampel dengan teknik clustering berdasarkan kriteria sebagai berikut: usia, jenis kelamin, tingkat edukasi, intensitas pemakaian smartphone, pernah memakai aplikasi di smartphone, dan pengetahuan akan aplikasi reservasi rumah sakit.

Penelusuran demografi rekam medik dilakukan untuk menentukan populasi sampel penelitian pada tahap penentuan target pengguna hingga evaluasi untuk mendukung pengembangan prototipe. Analisis demografi ini dilakukan dengan mendata rekam medik pasien dari 5 tahun pada kurun waktu 2015-2019. Tabel 1 memperlihatkan hasil analisis demografi yang diperoleh.

Tabel 1. Demografi Sosial Pasien RSGM Kurun Waktu 2015 - 2019

\begin{tabular}{ccc}
\hline $\begin{array}{c}\text { Modus Umur Tahun 2015- } \\
\text { 2019 }\end{array}$ & & 23 \\
\hline Jenis Kelamin & $\mathrm{P}$ & 52 \\
& Menikah & 97 \\
\hline Status Perkawinan & Belum Menikah & 88 \\
& N/A & 130 \\
Pekerjaan & IRT & 3 \\
\hline Wiraswasta & 19 \\
& Mahasiswa & 23 \\
& Pelajar & 49 \\
& Pegawai Swasta & 28 \\
& PNS & 25 \\
Pendidikan Terakhir & Lainnya & 6 \\
& Sarjana & 48 \\
\hline Jumlah Total Pasien & Diploma & 110 \\
$($ S015-2019) & SMA & 12 \\
& SMK & 63 \\
& SMP & 8 \\
& SD & 8 \\
& & $\mathbf{2 2 4}$ \\
\hline
\end{tabular}


Selain data pasien pada kurun waktu tersebut, terdapat 10 responden wawancara pada sesi perencanaan, dan diperbanyak menjadi 30 responden pada tahapan akhir uji usabilitas prototipe.

\subsection{Gambaran Sistem Reservasi Offline di RSGM}

Pelayanan rawat jalan di RSGM Unpad mempunyai standar prosedur operasional (SPO) alur antrian pasien selama rawat jalan. Aturan ini ditetapkan pada tahun 2018 dengan nomor surat B07-014. Secara rinci sistem reservasi oflline dapat dilihat pada Gambar 2. Gambaran sistem reservasi ini menjadi landasan konteks penggunaan untuk pengembangan tugas atau aksi mana yang diubah ke dalam mekanisme reservasi online dalam prototipe.

Gambar 2. Alur Reservasi Offline di RSGM Unpad

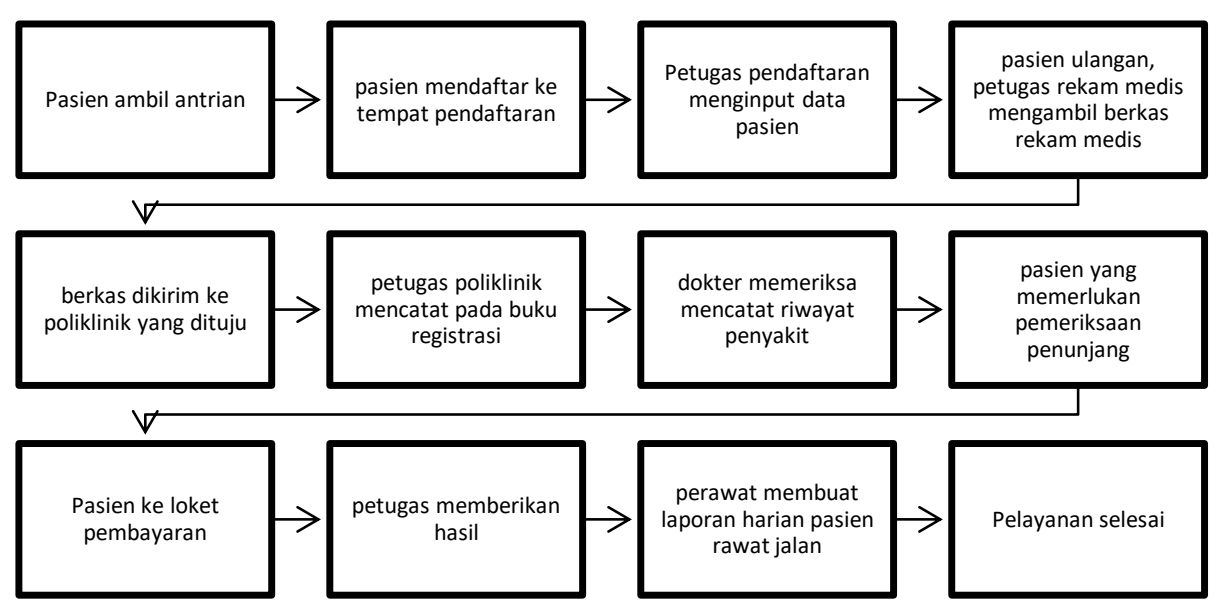

\section{Instrumen dan Alat Analisis}

Instrumen penelitian yang digunakan berupa poin pertanyaan wawancara yang diimplementasikan pada 10 responden awal serta admisi RSGM. Lalu pada akhir iterasi, uji usabilitas menggunakan kuisioner yang terdiri dari 7 aspek dengan total pertanyaan sebanyak 29. Jawaban pada kuisioner berupa penilaian skala Likert dengan rentang nilai 1 sampai 5. Nilai 1 mengindikasikan penilaian sangat rendah dan nilai 5 untuk sangat tinggi. Adapun proses pemetaan nilai kumulatif dari kuisioner menggunakan tendensi sentral berupa rata-rata (Boone, Harry N.; Boone, 2012) yang diskalakan ke 100 lalu dipetakan pada rentang kualitatif yang didapatkan dari: 


$$
I=\frac{100}{\text { jumlah skor Likert }}
$$

Jumlah skor Likert yang digunakan pada penelitian ini adalah 5 sehingga diperoleh rentang interpretasi berikut:

Tabel 2. Rentang Nilai untuk Intrepretasi Kualitatif

\begin{tabular}{cc}
\hline Rentang interval & Interpretasi Kualitatif \\
\hline $0 \%-19,99 \%$ & Sangat tidak baik \\
$20 \%-39,99 \%$ & Tidak baik \\
$40 \%-59,99 \%$ & Netral \\
$60 \%-79,99 \%$ & Baik \\
$80 \%-100 \%$ & Sangat Baik \\
\hline
\end{tabular}

\section{HASIL DAN DISKUSI}

\subsection{Penentuan Target Persona}

Pengembangan prototipe sistem reservasi daring RSGM ini ditujukan untuk target penggunga dengan persona sebagai berikut (lihat Tabel 3). Persona ini diperoleh dari analisa demografi pasien dan diperkuat dengan wawancara terhadap 10 pasien.

Tabel 3. Deskripsi Persona End User dari Prototipe Sistem Reservasi Daring RSGM

\begin{tabular}{ll}
\hline \multicolumn{1}{c}{ Aspek Persona } & \multicolumn{1}{c}{ Deskripsi } \\
\hline Usia & Modus: 23 tahun \\
Jenis Kelamin & Mendekati seimbang antara perempuan dan laki-laki \\
Pekerjaan & $\begin{array}{l}\text { Dominan telah bekerja (PNS, Wiraswasta, Pegawai Swasta, dan } \\
\text { lainnya) }\end{array}$ \\
Pendidikan Terakhir & Dominan SMA sederajat, Diploma dan Sarjana \\
\hline
\end{tabular}

Berdasarkan hasil wawancara terhadap 10 responden pasien, terdapat beberapa masalah mengenai reservasi offline yang berhasil diidentifikasi. Masalah tersebut antara lain: sistem antrian yang seperti puskesmas, alur antrian yang belum jelas dan kurang efisien. Hal ini menyebabkan lama menunggu pasien untuk berobat menjadi lebih lama. Oleh karena itu, repsonden berharap akan antrian yang lebih modern menggunakan alat elektronik dan aplikasi. 
Selain dari pengalaman responden mengenai situasi reservasi offline, diidentifikasi juga literasi digital dari para responden. Informasi mengenai literasi digital membantu peneliti mengembangkan prototipe sistem reservasi daring lebih tepat. Semua responden sudah mengetahui adanya aplikasi-aplikasi kesehatan yang dapat digunakan di smartphone, tetapi $90 \%$ belum pernah menggunakan aplikasi kesehatan tersebut untuk reservasi online ke dokter atau rumah sakit. Oleh karena itu, konteks penggunaan perlu dibuat sederhana dan mudah digunakan. Terdapat pula fitur-fitur yang diharapkan responden dapat tersedia di sistem reservasi daring antara lain: pendaftaran daring, pembatalan janji, penjadwalan ulang dan dapat melihat riwayat pengobatan.

Selain wawancara dengan 10 responden pasien, diidentifikasi pula informasi permasalahan reservasi rawat jalan offline dari persona pendukung yaitu admisi RSGM. Hasil wawancara dengan admisi RSGM Unpad menunjukkan aplikasi administrasi saat ini masih sering mengalami kendala, salah satunya adalah kendala dalam perekaman dan temu kembali data pasien yang dilakukan secara manual. Hal inilah yang membuat proses reservasi dan penjadwalan membutuhkan waktu yang lama. Oleh karena itu, petugas mengharapkan adanya aplikasi yang memudahkan admisi dalam pengelolaan penjadwalan dan pengelolaan data pasien.

\subsection{Hasil Pengembangan Prototipe}

Pengembangan prototipe diawali dengan low fidelity prototyping berupa wireframe. Wireframe diimplementasikan berdasarkan alur navigasi yang diperoleh dari hasil analisa konteks pengunaan dan target pengguna. Alur navigasi pada prototipe sistem reservasi daring RSGM untuk target pengguna dapat dilihat pada Gambar 3. Terdapat tujuh fitur utama di dalam prototipe yaitu: registrasi, login, cari dokter, daftar reservasi, info kesehatan gigi dan mulut, agenda, serta profil. 
Gambar 3. Alur Navigasi Sistem Reservasi Daring RSGM Unpad Bagi End-User

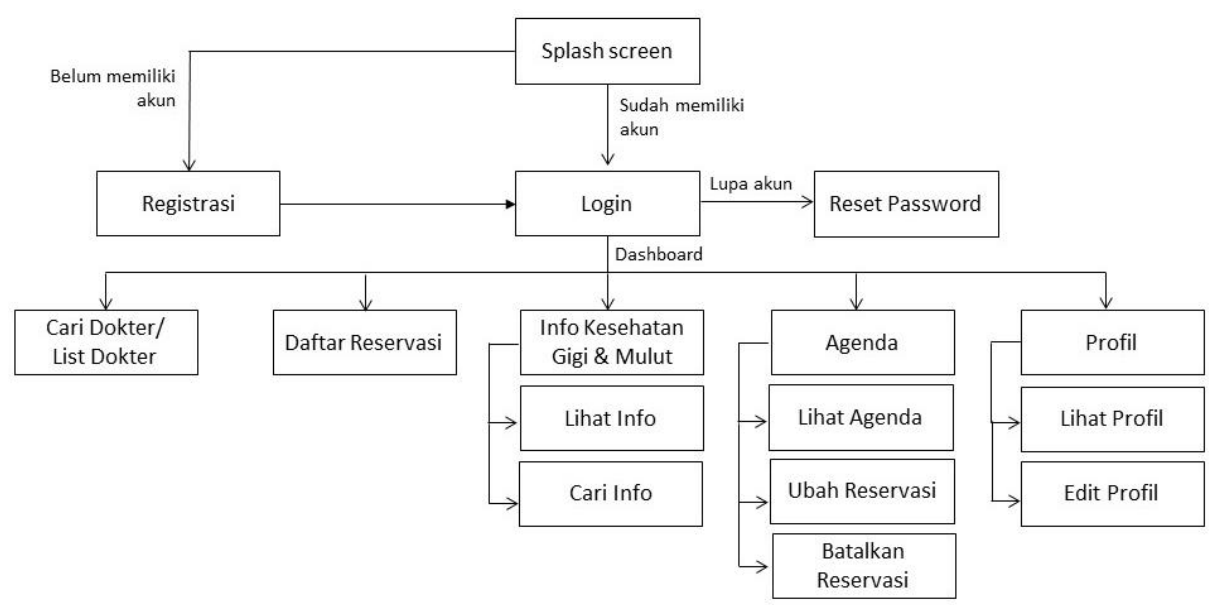

Selanjutnya wireframe yang dibuat dievaluasi secara internal ke 10 responden dan admisi RSGM. Setelah mendapatkan saran, masukan dan persetujuan, dikembangkanlah prototipe versi high fidelity. Sebagian screen shot prototipe dapat dilihat pada Gambar 4 dan Gambar 5.

Gambar 4. Screen Shot Prototipe Sistem Reservasi Daring RSGM Unpad: Pengguna Diarahkan Registrasi, Login dan Masuk ke Dashboard
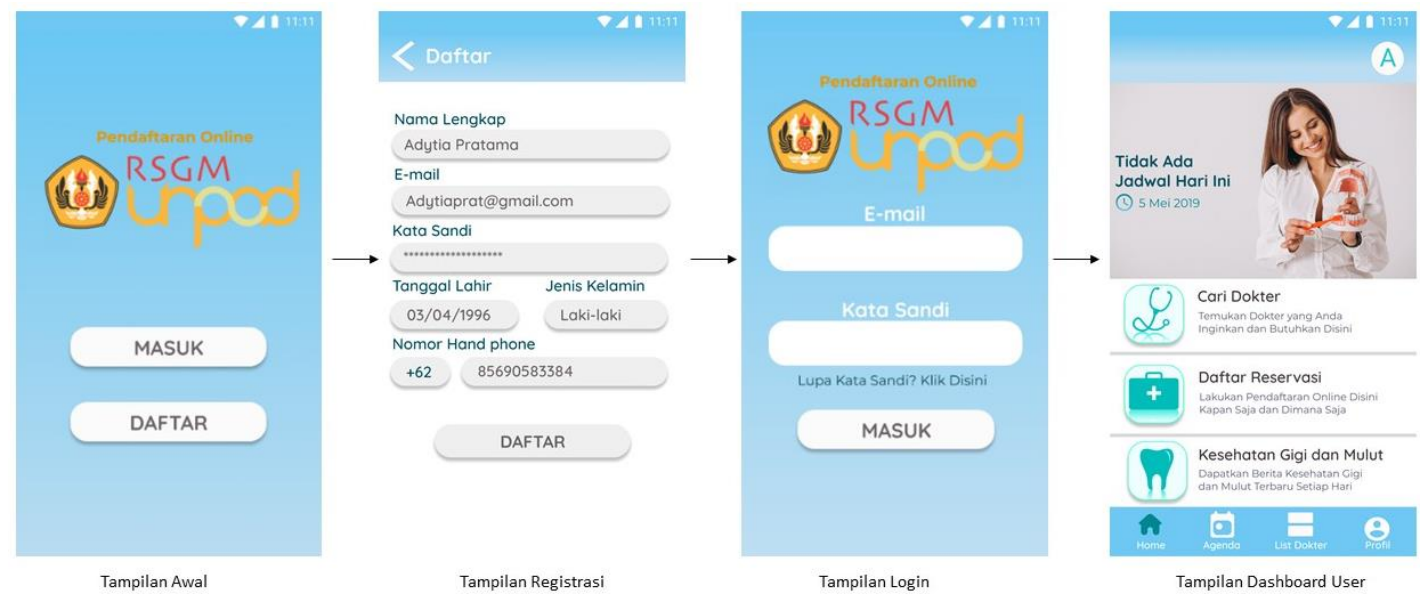

Pada tampilan awal, prototipe menunjukkan tombol daftar dan masuk. Pengguna sebagai pasien baru dapat menekan tombol daftar sehingga akan muncul halaman daftar akun. Setelah semua data terisi dapat menekan tombol daftar. Verifikasi akun akan dikirimkan ke email, lalu pengguna diarahkan ke halaman login. Email dan kata sandi diperlukan untuk masuk ke dalam sistem. Setelah berhasil login, tampilan dashboard pengguna akan muncul. 
Gambar 5. Screen Shot Prototipe Sistem Reservasi Daring RSGM Unpad: Alur Reservasi Daring Dokter Gigi

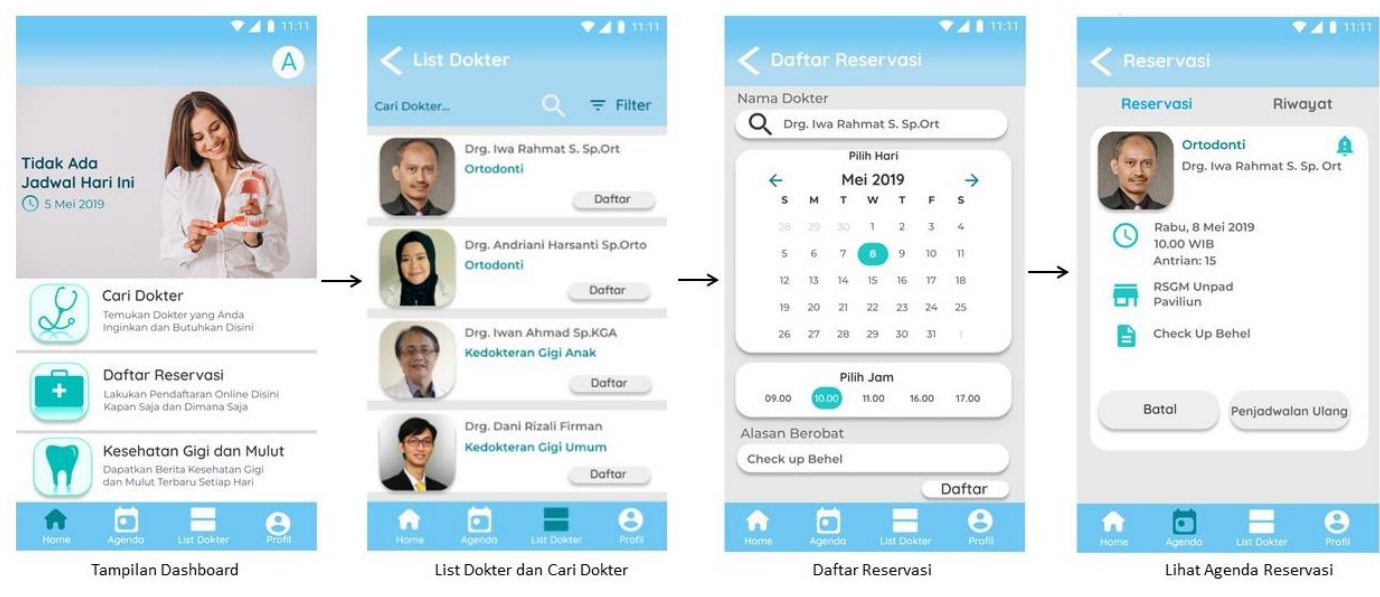

Sebagaimana diilustrasikan pada Gambar 5, proses reservasi dapat dilakukan melalui menu cari dokter atau mengakses list dokter pada tab bar. Pengguna diarahkan ke tampilan daftar dokter. Pengguna juga dapat memanfaatkan fitur cari dokter untuk mengefektifkan waktu dan klik daftar untuk mengisi detil reservasi. Selanjutnya pengguna diarahkan untuk melengkapi data tanggal, waktu, dan alasan berobat. Hasil reservasi dapat dilihat pada menu Agenda.

Dari sisi admisi, prototipe sistem memungkinkan admisi untuk mendaftarkan pasien yang datang langsung ke lokasi. Penjadwalan dilakukan dengan penggabungan sistem online dan offline berdasarkan waktu reservasi, sehingga prototipe sistem ini mengadopsi stochastic online.

\subsection{Hasil dan Analisa Uji Usabilitas}

Evaluasi terhadap pengguna dilakukan dengan cara uji coba langsung. Hasil evaluasi yang di dapat berasal dari 30 pengguna (10 pengguna sama dengan diawal) dan 20 pengguna tambahan baru. Responden diminta mencoba prototipe lalu menjawab 29 pertanyaan usabilitas untuk tujuh aspek, rekap uji dapat dilihat pada Tabel 4 berikut.

Tabel 4 Rekapitulasi Penilaian Usabilitas Prototipe Sistem Reservasi Daring RSGM Unpad

\begin{tabular}{clccc}
\hline No & \multicolumn{1}{c}{ Aspek } & Rata-rata & Persentase & Interpretasi \\
\hline 1 & Efektivitas \& Efisiensi & 4,10 & 82,00 & Sangat Baik \\
2 & Respon Waktu & 4,37 & 87,40 & Sangat Baik \\
3 & Tingkat Kepuasan & 4,29 & 85,80 & Sangat Baik \\
4 & Kemudahan Dipelajari & 4,11 & 82,20 & Sangat Baik \\
5 & Kemudahan Diingat & 3.75 & 75,00 & Baik \\
6 & Penanganan Error & 2.21 & 44,20 & Netral \\
7 & Beban Kognitif & 3.75 & 75,00 & Baik \\
\hline & Intepretasi Keseluruhan & $\mathbf{3 , 8 0}$ & $\mathbf{7 5 , 9 4}$ & Baik \\
\hline
\end{tabular}


Berdasarkan hasil uji usabilitas prototipe, persepsi responden terhadap uji efektivitas dan efisiensi adalah sangat tinggi dengan nilai rata-rata 4,27. Nilai yang tinggi didapatkan karena beberapa justifikasi, antara lain: Pertama, responden mendapatkan akses personal untuk melakukan pendaftaran; Kedua, responden mendapatkan fleksibilitas dalam proses pendaftaran; Ketiga, responden percaya bahwa aplikasi ini dapat meningkatkan mutu pelayanan RSGM; Keempat, responden mendapatkan informasi dan proses komunikasi yang lebih baik dengan RSGM; dan Kelima, responden menilai aplikasi ini mudah dimengerti dengan penggunaan bahasa dan instruksi yang tidak bertele-tele.

Dilihat dari aspek respon waktu, prototipe mendapatkan penilaian yang sangat tinggi dengan nilai rata-rata yaitu 4,37. Berkenaan dengan ini, responden menyampaikan prototipe dapat mempercepat proses booking dan lebih cepat mengetahui jadwal dokter yang tersedia tanpa harus menghubungi RSGM. Selain itu, respon sebagai feedback dari prototipe terhadap aksi yang dilakuan responden sangat baik.

Prototipe juga memberikan tingkat kepuasan yang sangat baik bagi responden dengan nilai 4,29. Responden menilai proses reservasi offline dapat dengan baik ditransformasikan ke mode online, sehingga dapat meningkatkan kualitas pelayanan RSGM. Proses reservasi memberikan pengalaman baru yang menyenangkan bagi responden dan merasa dekat dengan dokter yang akan menanganinya.

Literasi digital yang baik dari responden menjadi modal pendukung dalam mengoperasikan prototipe. Selain itu proses pengoperasian prototipe mudah dipelajari dengan adanya pemberian informasi dan instruksi sederhana, mudah dibaca, dan link yang mudak diklik. Kemudahan ini memberikan beban kognitif yang rendah dan ingatan yang relatif lebih sedikit.

Namun, perbaikan perlu difokuskan pada aspek penanganan error, perlu ada feeback untuk setiap aksi tidak hanya untuk input yang benar tetapi juga untuk input yang salah ke sistem. Pengguna masih merasa bingung pada beberapa bagian apabila input yang dimasukkan tidak tepat. 


\subsection{Diskusi}

Berdasarkan hasil wawancara pada tahap awal pengembangan prototipe, responden menyatakan alur antrian pendaftaran offline terlalu lama menyebabkan tingkat kepuasan responden sebagai pasien berkurang. Hal ini sesuai dengan pernyataan Zhao et al. (2017) bahwa waktu tunggu pendaftaran merupakan salah satu indikator kualitas pelayanan, sehingga berpotensi menimbulkan ketidakpuasan yang mempengaruhi hasil perawatan kesehatan. Hasil wawancara menyatakan bahwa semua responden (100\%) mengharapkan adanya aplikasi pendaftaran daring. Sebanyak $40 \%$ responden menyatakan dukungan adanya aplikasi dengan menambahkan secara spesifik fitur-fitur yang diinginkan dan $60 \%$ responden menyatakan dukungannya saja.

Fitur utama dalam prototipe penelitian ini adalah fitur pendaftaran daring. Fitur ini dianggap penting oleh Yang et al. (2019) karena memberikan akses personal kepada pasien untuk menjadwalkan hari berobatnya sendiri. Dengan adanya prototipe tersebut responden mengharapkan proses pendaftaran pasien bisa menjadi lebih efisien dan informasi yang diperlukan untuk mendaftar bisa diakses langsung secara personal. Selain itu, pasien mengharapkan adanya fitur pengingat dalam aplikasi dengan cara notifikasi aplikasi atau chat WA. Hal ini penting dimasukan dalam aplikasi menurut Zhao et al. (2017) yang menyatakan adanya fitur pengingat membantu mengurangi kejadian pasien tidak datang terutama karena lupa.

Hasil wawancara juga menjelaskan pasien setuju dengan fitur yang akan muncul dalam prototipe yaitu, fitur pendaftaran online, pengingat berobat, riwayat pengobatan, pembatalan dan pembuatan jadwal ulang. Fitur lain yang diharapkan responden adalah fitur pembatalan. Fitur ini diharapkan memiliki batas waktu paling lambat 24 jam sebelum waktu yang sudah dijadwalkan. Sebanyak 90\% responden mengharapkan adanya fitur penjadwalan ulang yang dapat dilakukan oleh pasien sendiri, sedangkan hanya $10 \%$ saja yang menginginkan fitur dilakukan oleh perawat. Selain fitur-fitur di atas, diharapkan aplikasi pendaftaran daring RSGM diharapkan adanya fitur konsultasi daring dan berita kesehatan. Hal ini diharapkan oleh $40 \%$ pasien dengan permintaan konsultasi daring, $50 \%$ permintaan fitur informasi kesehatan dan $10 \%$ tidak mengemukakan permintaan.

Hasil kuisoner menyatakan prototipe yang dibuat sesuai dengan keinginan pasien dalam aspek efektivitas, efisiensi, respon waktu, kepuasaan, beban kognitif yang 
rendah, mudah dipelajari dan digunakan. Namun, perlu diperbaiki dari sisi penanganan error. Penggunaan metodologi user centered design membuat prototipe selalu dalam jalur keinginan target pengguna, sehingga dari sisi biaya lebih efektif dan meminimalisasi kegagalan

\section{KESIMPULAN}

Prototipe sistem reservasi daring RSGM Unpad dapat membantu pengguna melakukan reservasi dokter gigi. Hal ini dilihat dari hasil wawancara dengan $100 \%$ responden yang menyatakan harapan adanya aplikasi pendaftaran daring di RSGM Unpad. Prototipe yang telah dikembangkan menggunakan metode user centered design berhasil memenuhi kebutuhan dari target penggunanya. Hal ini dapat dilihat dari tingkat usabilitas prototipe pada kategori baik dengan nilai skala Likert 3,80 dari 5,0 Upaya penyempurnaan prototipe perlu terus dilakukan, banyak terkait dengan reservasi yang belum diinvestigasi seperti penambahan persona ketiga selain pasien dan admisi, yaitu dokter gigi. Reservasi dapat menjadi lebih kompleks apabila dokter gigi dapat memiliki keleluasaan membatalkan janji pemeriksaan.

\section{ACKNOWLEDMENTS}

Para peneliti menyampaikan terima kasih kepada para narasumber baik pasien maupun admisi RSGM Universitas Padjadjaran yang bersedia memberikan informasi dan data terkait penelitian ini.

\section{DAFTAR PUSTAKA}

Ahmadi-Javid, A., Jalali, Z., \& Klassen, K. J. (2017). Outpatient appointment systems in healthcare: A review of optimization studies. In European Journal of Operational Research. https://doi.org/10.1016/j.ejor.2016.06.064

Berg, Bjorn P.; Denton, Brian T.; Erdogan, S. Ayca; Rohleder, T.; Huschka, T. (2014). Optimal Booking and Scheduling in Outpatient Procedure Centers. Computers \& Operations Research, 50, 24-37. https://doi.org/https://doi.org/10.1016/j.cor.2014.04.007

Boone, Harry N.; Boone, D. A. (2012). Analyzing Likert Data. Journal of Extension, 66(8), 1456-1466. https://doi.org/10.1007/s11172-017-1908-3 
Chammas, A., Quaresma, M., \& Mont'Alvão, C. (2015). A Closer Look on the User Centred Design. Procedia Manufacturing, 3(Ahfe), 5397-5404. https://doi.org/10.1016/j.promfg.2015.07.656

Chen, Y., Kuo, Y. H., Fan, P., \& Balasubramanian, H. (2018). Appointment overbooking with different time slot structures. Computers and Industrial Engineering. https://doi.org/10.1016/j.cie.2018.07.021

Kurtzman, G. W., Keshav, M. A., Satish, N. P., \& Patel, M. S. (2018). Scheduling primary care appointments online: Differences in availability based on health insurance. Healthcare. https://doi.org/10.1016/j.hjdsi.2017.07.002

Marynissen, J., \& Demeulemeester, E. (2019). Literature review on multi-appointment scheduling problems in hospitals. In European Journal of Operational Research. https://doi.org/10.1016/j.ejor.2018.03.001

Parsazadeh, N., Ali, R., Rezaei, M., \& Tehrani, S. Z. (2018). The construction and validation of a usability evaluation survey for mobile learning environments. Studies in Educational Evaluation. https://doi.org/10.1016/j.stueduc.2018.06.002

Römer, T., \& Bruder, R. (2015). User Centered Design of a Cyber-physical Support Solution for Assembly Processes. Procedia Manufacturing, 3(Ahfe), 456-463. https://doi.org/10.1016/j.promfg.2015.07.208

Saito, S., \& Ogawa, K. (1994). Ergonomics of human-system interaction. The Japanese Journal of Ergonomics, 30(1), 1-1. https://doi.org/10.5100/jje.30.1

Siddiqui, M. I. (2016). Hospital Administration and Management. In Community Medicine and Public HealthEdition (8th Ed). Time Publishers. https://doi.org/10.13140/RG.2.1.2566.6327

Smaradottir, B., \& Fensli, R. (2016). User-centred Design of Health Information Technology. International Journal of Integrated Care, 16(5), 38. https://doi.org/10.5334/ijic.2587

Song, J., Bai, Y., \& Wen, J. (2019). Optimal Appointment Rule Design in an Outpatient Department. IEEE Transactions on Automation Science and Engineering. https://doi.org/10.1109/TASE.2018.2794335

Wang, J., Chen, Y. (Frank), \& Xu, M. (2018). Optimization and approximation methods for dynamic appointment scheduling with patient choices. Computers and Operations Research. https://doi.org/10.1016/j.cor.2017.12.009

Xu, Z., Chen, Z., Eutsler, L., Geng, Z., \& Kogut, A. (2019). A scoping review of digital game-based technology on English language learning. Educational Technology Research and Development. https://doi.org/10.1007/s11423-019-09702-2

Yang, P. C., Chu, F. Y., Liu, H. Y., Shih, M. J., Chen, T. J., Chou, L. F., \& Hwang, S. J. (2019). Features of online hospital appointment systems in Taiwan: A nationwide survey. International Journal of Environmental Research and Public Health. https://doi.org/10.3390/ijerph16020171 
Zhao, P., Yoo, I., Lavoie, J., Lavoie, B. J., \& Simoes, E. (2017). Web-based medical appointment systems: A systematic review. Journal of Medical Internet Research, 19(4). https://doi.org/10.2196/jmir.6747 